\title{
Microbial Diversity in the Peri-Implant Region of Patients with History of Periodontal Disease and Clinical Parameters
}

\author{
Diversidlade Microbiana em Região Peri-Implantar de Pacientes com Histórico de Doença \\ Periodontal e Parâmetros Clínicos \\ Diversidad Microbiana em la Región Periimplantaria de Pacientes Con Antecedentes de \\ Enfermedad Periodontal y Parámetros Clínicos
}

Received: 02/09/2022 | Reviewed: 02/15/2022 | Accept: 02/19/2022 | Published: 03/01/2022

Tassiana Carvalho Mendonça Galvão ORCID: https://orcid.org/0000-0003-4838-0164

University of Uberaba, Brazil

E-mail: tassiana2512@hotmail.com

Juliana Barbosa de Faria

ORCID: https://orcid.org/0000-0002-9681-2278

Federal University of Triangulo Mineiro, Brazil

E-mail: julibfaria@hotmail.com

Luís Henrique Borges

ORCID: https://orcid.org/0000-0001-8573-9848

Universidade Federal do Triângulo Mineiro, Brazil

E-mail: luis.borges@uniube.br

Camilla Beatriz da Silva

ORCID: https://orcid.org/0000-0002-4387-2189 University of Uberaba, Brazil

E-mail: beatriz.camilla@ hotmail.com

Eleonora de Paula Amaral

ORCID: https://orcid.org/0000-0002-3107-2002 University of Uberaba, Brazil

E-mail: eleonoramaral@yahoo.com

Bárbara Bellocchio Bertoldo

ORCID: https://orcid.org/0000-0003-0628-9792 Federal University of Triangulo Mineiro, Brazil

E-mail: barbarabellocchiob@hotmail.com

Taíssa Cássia de Souza Furtado ORCID: https://orcid.org/0000-0002-8186-1798 University of São Paulo, Brazil

E-mail: taissacassia@hotmail.com

Denise Bertulucci Rocha Rodrigues

ORCID: https://orcid.org/0000-0003-4003-542X University of Uberaba, Brazil Federal University of Triangulo Mineiro, Brazil E-mail: denise.rodrigues@uniube.br

Vinicius Rangel Geraldo Martins ORCID: https://orcid.org/0000-0002-4312-3073 University of Uberaba, Brazil

E-mail: vinicius.martins@uniube.br

Sanivia Aparecida de Lima Pereira ORCID: https://orcid.org/0000-0002-0293-2587 University of Uberaba, Brazil Federal University of Triangulo Mineiro, Brazil E-mail: sanivia.pereira@uniube.br

Ruchele Dias Nogueira ORCID: https://orcid.org/0000-0002-7706-1376 University of Uberaba, Brazil

E-mail: ruchele_nogueira@yahoo.com.br

\begin{abstract}
Although implant rehabilitations are successful, a small portion of patients may present peri-implant mucositis and peri-implantitis due to the bacteria biofilm formation. The purpose of the present study was to evaluate the presence of Porphyromonas gingivalis (Pg), Prevotella intermedia (Pi), Fusobacterium nucleatum (Fn) and Scardovia wiggsiae
\end{abstract}


(Sw) in Peri-implant gingival Fluid (PGF) of patients who received implants 12 months ago and associated with periodontitis (PD) history and clinical data. Samples were collected from 44 volunteers and analyzed by PCR with specific primers. The results showed that Pg were detected in 34\%, Fn and Pi, 81.8\%, and Sw $75 \%$ of the volunteers. Pg was frequently detected in patients who had a history of PD $(p<0.05, q=8.19)$, but no statistically significant differences for $\mathrm{Fn}, \mathrm{Pi}$, and $\mathrm{Sw}(\mathrm{p}>0.05, \mathrm{q}<0.61)$. Pg was detected in $58.3 \%$ of the volunteers who had teeth prior to implants and their presence was associated with periodontitis $(\mathrm{p}<0.05, \mathrm{q}=5.31)$ and gingivitis $(\mathrm{p}<0.05, \mathrm{q}=4.31)$. All the patients whose probing depths were greater than $3 \mathrm{~mm}$ had $\mathrm{Fn}$ in detectable levels $(\mathrm{p}<0.05, \mathrm{q}=4.56)$. In conclusion, the involvement of $\mathrm{Sw}$ in peri-implant alterations was not evident in this work. The presence of $\mathrm{Pi}$ and $\mathrm{Fn}$ were not related to history of PD and mucositis. Fn was present in periodontal pockets above $3 \mathrm{~mm}$, suggesting its involvement in peri-implant alterations. Pg was detected in patients with a history of PD, gingivitis, and periodontitis and in those who had teeth before the implant installation.

Keywords: Biofilm; Dental implants; Peri-implant mucositis; Peri-implantitis.

\begin{abstract}
Resumo
Embora as reabilitações com implantes sejam bem-sucedidas, uma pequena parcela dos pacientes pode apresentar mucosite e periimplantite devido à formação de biofilme bacteriano. O objetivo do presente estudo foi avaliar a presença de Porphyromonas gingivalis (Pg), Prevotella intermedia (Pi), Fusobacterium nucleatum (Fn) e Scardovia wiggsiae ( $\mathrm{Sw}$ ) no Fluido Gengival Periimplantar (FGP) de pacientes que receberam implantes 12 meses atrás e associar com história de periodontite (PD) e dados clínicos. As amostras foram coletadas de 44 voluntários e analisadas por PCR com primers específicos. Os resultados mostraram que Pg foi detectado em 34\%, Fn e Pi, 81,8\%, e Sw 75\% dos voluntários. A Pg foi detectada com frequência em pacientes com história de DP (p<0,05, q=8,19), mas não houve diferenças estatisticamente significativas para Fn, Pi e $\mathrm{Sw}(\mathrm{p}>0,05, \mathrm{q}<0,61)$. A Pg foi detectada em 58,3\% dos voluntários que tinham dentes anteriores aos implantes e sua presença foi associada à periodontite $(\mathrm{p}<0,05$, $q=5,31)$ e gengivite $(p<0,05, q=4,31)$. Todos os pacientes cujas profundidades de sondagem foram maiores que $3 \mathrm{~mm}$ apresentaram Fn em níveis detectáveis $(p<0,05, q=4,56)$. Em conclusão, o envolvimento do SW nas alterações periimplantares não foi evidenciado neste trabalho. A presença de Pi e Fn não teve relação com a história de DP e mucosite. Fn esteve presente em bolsas periodontais acima de $3 \mathrm{~mm}$, sugerindo seu envolvimento em alterações periimplantares. A Pg foi detectada em pacientes com histórico de DP, gengivite e periodontite e naqueles que possuíam dentes antes da instalação do implante.
\end{abstract}

Palavras-chave: Biofilmes; Implantação dentária; Mucosite peri-implantar; Peri-implantite.

\title{
Resumen
}

Aunque las rehabilitaciones con implantes tienen éxito, una pequeña proporción de pacientes puede tener mucositis y periimplantitis debido a la formación de biopelículas bacterianas. El objetivo del presente estudio fue evaluar la presencia de Porphyromonas gingivalis (Pg), Prevotella intermedia (Pi), Fusobacterium nucleatum (Fn) y Scardovia wiggsiae ( $\mathrm{Sw}$ ) en el Fluido Gingival Periimplantario (PGF) de pacientes que recibieron implantes. Hace 12 meses y asociado a antecedentes de periodoncia (PD) y datos clínicos. Se recolectaron colecciones de 44 unidades y unidades por PCR con especificaciones de cebadores. Los resultados de 34\% que se detectaron Pg en Fn y Pi, 8,8\%, y S 75\% de los voluntarios. La Pg se registró con frecuencia en pacientes con EP ( $<<0,05, \mathrm{q}=8,19)$, pero no hubo diferencias estadísticamente significativas para Fn, Pi y Sw (p>0,5, q<0,61) ). Pg estuvo presente en el 58,3\% de los dientes voluntarios antes de los implantes $(\mathrm{p}<0,05, \mathrm{q}=5,31)$ y gingivitis $(\mathrm{p}<0,05, \mathrm{q}=4,31)$. Todos los pacientes cuyas profundidades de sondaje eran superiores a $3 \mathrm{~mm}$ tenían ( $\mathrm{Fn}$ en niveles detectables $\mathrm{p}<0,05$, q=4,56). En conclusión, la participación de SW en los cambios periimplantarios no se evidenció en este trabajo. La presencia de Pi y Fn no se relacionó con el antecedente de EP y mucositis. Fn presente en bolsas periodontales mayores de $3 \mathrm{~mm}$, lo que sugiere su implicación en alteraciones periimplantarias. Pg fue diseñado en pacientes, gingivitis y periodontitis, que tenían dientes antes de la instalación.

Palabras clave: Biofilm; Implantes dentales; Mucositis periimplantaria; Periimplantitis.

\section{Introduction}

Dental implants have become a revolutionary tool in reconstructive dentistry, replacing missing teeth and restoring aesthetics, in addition to masticatory and occlusion functions (Belibasakis \& Manoil, 2021) and are defined as devices for oral rehabilitation (Ogle, 2015). They have been used since 1965, when Brånemark's studies (Albrektsson \& Isidor, 1994) started, and are becoming viable and efficient to replace missing teeth in partially and completely edentulous patients (Wang et al., 2017). Basically, they are formed by a metal screw and a pillar, which are analogous to the dental root (Petkovic-Curcin et al., 2011). The materials for dental implants manufacturing are mainly titanium or a titanium alloy, since these materials are highly resistant to corrosion and tension, and are resistant, resilient, with stability and low density (Ottria et al., 2018; De Oliveira et 
al., 2017). The relations between implant and bone take place through osseointegration, which happens when the bone is in intimate contact with the implant in a predictable way, so it can serve as the base for the implant (Mendes \& Davies, 2016). Some factors can enhance or inhibit osseointegration. The factors that enhance it are related to the implant, its design, composition, topography, material, length, form, diameter, the treatment of its surface, the state of the patient's bone tissue, mechanical stability, bone grafts, and pharmacological agents. The factors that may inhibit it include the lack of primary stability, inadequate roughness, radiotherapy, medications, and factors related to the patient, such as systemic diseases and the accumulation of biofilm due to an inadequate hygiene (Mavrogenis et al., 2009).

The peri-implant mucosa is the soft tissue around the dental implants. It is established during the healing process and its clinical and histological characteristics are like those of the gingiva that surrounds natural teeth (Lindhe \& Karring, 2010), which means that there may be inflammatory responses in the gingival tissue when there is too much accumulated bacteria biofilm (Zitzmman et al., 2001). The fibrous tissues in the implants are different from the tissues inserted in the teeth, since they are less vascularized and the direction of the collagen fibers is parallel, resulting in a more profound sulcus than the gingival one. Dental implants are more susceptible to endogenous infections due to these differences when compared to natural teeth (Belibasakis, 2014). The osseointegration success of dental implants is related to the absence of clinical inflammation and suppuration signs, and no probing depths below $2 \mathrm{~mm}$ (Sanz \& Chaple., 2012). On the other hand, dental implants may be unsuccessful due to many causes, such as peri-implant diseases, which include mucositis and peri-implantitis, periodontal pathological alterations that affect the implants predictability (Derks \& Tomasi, 2015; Lindhe \& Meyle, 2008). Mucositis is characterized by reversible inflammatory changes in the peri-implant gingival tissues without bone loss; peri-implantitis, on the other hand, are inflammatory reactions with the bone support loss in the implant surrounding tissues.

Peri-implant mucositis is caused by the biofilm accumulation, with dysbiosis in the implant interface, leading to an inflammatory process. It is a reversible condition after which the host can become healthy (Heitz-Mayfield \& Salvi, 2018). The diagnosis of mucositis must be based on the presence of peri-implant inflammation (redness, edema, bleeding), combined with no additional bone loss (Renvert et al., 2018). Conversely, peri-implantitis is one of the main causes of implant failure (De Oliveira et al., 2015), leading to the loss of bone support and in some cases of the implant itself (Diógenes et al.; 2018). This disease takes place due to a biofilm dysbiosis in the peri-implant region (Pita, 2015) and can be related to mucositis evolution. Ecological changes in the peri-implant sites may lead to microbiota changes, favoring dysbiosis through the overgrowth of potentially pathogenic bacteria, thus increasing the odds of developing peri-implantitis (Kroger et al., 2018). Some clinical characteristics can be observed in this inflammatory process, including bleeding on probing, exudate, increased probing depth, and edema (Martins et al., 2019). Clinically, peri-implantitis is the formation of peri-implant pockets deeper than 3 mm, in addition to bleeding on probing and/or suppuration. Radiographically, it is diagnosed when bone loss is observed around the implant, which is represented by peri-implant radiolucency caused by the loss of bone support (Heitz-Mayfield et al.; 2008). Another study considered peri-implantitis as the horizontal bone loss of $3 \mathrm{~mm}$ or more around the implant, with physiological bone loss from 1 to $1.5 \mathrm{~mm}$ (Casado et al., 2011; Oliveira et al., 2013).

There is much controversy about the composition of the biofilm in peri-implant infections; whether it is different from the composition of biofilm periodontitis sites or is common to the microflora around healthy dental implants (Sahrmann et al., 2020). Microbe colonization of the peri-implant region immediately after the implants are placed seem to be like healthy periodontal sites, with less diversity (Heitz-Mayfield e Salvi; 2018). Therefore, the microbe colonization of the natural teeth may be used as a reservoir to form the biofilm around the implant (Valente \& Adreana, 2016; Yan et al., 2020). Kocar et al. (2010) showed that the peri-implant and periodontal sites of partially edentulous patients showed no differences in their microbiota, showing the same periodontal pathogenic species, while none of these bacteria were found in the peri-implant sites of completely edentulous patients. The implants, when installed in previously infected sites, have higher failure risk when 
compared to immediate dental implants placed in non-infected sites (Oliveira- Neto et al., 2019).

The microbiota associated with the peri-implant disease is formed by many microorganisms, such as Aggregatibacter actinomycetemcomitans, Porphyromonas gingivalis, Prevotella intermedia, Fusobacterium nucleatum, Tannerella forsythensis, and Campylobacter rectus (Cerbasi, 2010). The subgingival biofilm in teeth with periodontitis seems comparable (Cerbasi, 2010). Healthy sites presented another microbiota, formed by Streptococcus mitis, Streptococcus salivaris, Actynomices naeslundi, and Actionomyces odontolycus (Petrasunas, 2010; Sobreira et al., 2011). These microorganisms can damage peri-implant tissues in many ways: invading and damaging them by the liberation of enzymes, subproducts, and bone reabsorption factors; lowering the defenses of the host; inducing an inflammatory response mediated by the host immune system (Cerbasi, 2010). Peri-implant colonization starts 30 minutes after the implant is placed, and the bacterial load stays the same in the first week (Furst et al, 2007). Between the first and twelfth week, after the surgical procedure, there are high levels of Porphyromonas gingivalis, Tanerella forsythia, and Treponema denticola. At 12 months, the bacterial load seems to be significantly higher for some species, especially for T. forsythia and, in a lower level, P. gingivalis (Salvi et al., 2008). According to Tallarico (2017), bacterial count in peri-implantitis diseases present an increase in the colonization of $T$. forsythia.

Scardovia wiggsiae is an anaerobic microorganism, a pleomorphic gram-positive bacillus recently isolated from the human oral cavity. It is associated with early cavities and was later isolated in the periodontal pockets of adults who underwent orthodontic treatment (Tanner et al., 2012). Its role in the etiology of the disease and in periodontal health is still the target of controversy. A recent study has shown the presence of $S$. wiggsiae in periodontal sites, indicating a diminution of its concentration in the subgingival plaque of periodontally healthy patients who had, respectively, gingivitis and chronic periodontitis (Chakrapani et al., 2019). However, no studies associate its presence with the peri-implant sites.

In addition to the peri-implant biofilm, other factors may lead to the peri-implant bone loss, such as occlusion overload, genetic factors, local factors, early exposure of the implant, systemic problems, inadequate hygiene, smoking, and patients with a history of periodontitis (Romeiro et al.; 2010; Feres et al.; 2008). Among these, a history of periodontitis is associated with a considerable risk of peri-implant mucositis or even peri-implantitis (Altay et al., 2018; Yan et al., 2020). Patients with a history of periodontal diseases are six times more likely to have peri-implantitis (Francio et al., 2008).

The accumulation of biofilm in the peri-implant region may lead to the loss of the implant (Esposito et al., 2008; Shibli \& D'avila, 2006), due to the inflammatory response of the tissues around the implant (Louropoulou et al., 2012) when in the presence of microorganisms (Lindhe \& Meyle, 2008). It is important to notice that the beginning of peri-implantitis and its progression do not depend only on the presence of bacteria biofilm and its composition, it also depends on risk factors and diseases that affect health (Kumar, 2019). Thereafter, understanding peri-implant mucositis and peri-implantitis (HeitzMayfield \& Salvi, 2018) is paramount, since the peri-implant microbiota becomes more complex as the infection advances (Belibasakis \& Manoil, 2021). The purpose of the present study was to evaluate the presence of Porphyromonas gingivalis (Pg), Prevotella intermedia (Pi), Fusobacterium nucleatum (Fn) and Scardovia wiggsiae ( $\mathrm{Sw}$ ) in Peri-implant gingival Fluid (PGF) of patients who received implants 12 months ago and associated the presence of these microorganisms with periodontitis (PD) history and clinical data.

\section{Methodology}

\section{Sample selection and collection}

This study was approved by the Ethics Committee from the Uberaba University, Brazil (CAAE: 64947717.0.0000.5145). All eligible patients were informed about the nature of the study and about the potential risks and 
benefits of participating by signing the Free and Informed Consent Form (FICF). The clinical investigation was carried out according to the principles from the Declaration of Helsinki. The patients were selected for dental implants follow-up, during the period of 1 year from February 2019 to February 2020 in the Odontology Clinic of the Uberaba University. Medical and dental information were obtained from the patients who agreed participating in the study and were in accordance with the inclusion/exclusion criteria. The patients $(\mathrm{n}=44)$ were examined and interviewed in two moments: at admission for the fixed unitary rehabilitation with Pross ${ }^{\circledR}$ Morse Taper Cylindric impant (Dabi Atlante, São Paulo, Brasil) and 12 months after the implants were placed. The installation was carried out by a single specialist dentist (E.P.A.). The criteria for inclusion/exclusion were patients with good general health and sign the FICF. Were excluded all patients with parafunctional habits, smokers and alcoholics, edentulous patients, those who had been using corticoids, antibiotics, or anti-inflammatory medication in the last six months, who had undergone periodontal or peri-implant therapy after installing the implant, who had relevant uncompensated systemic diseases, such as diabetes and osteoporosis. After the FICF was signed, the patients were interviewed about their health, habits and history of oral diseases, and use of medication. Afterwards, the participants were submitted to an intraoral clinical examination by the same dentist in both visits. The patient was evaluated regarding oral conditions, and there was an inspection of periodontal diseases, cavities, and the previous presence of teeth in the site who would receive the implant. The implants were analyzed regarding local inflammatory process. Then, the interface between tooth and implant was probed.

The following parameters were evaluated in six sites (mesio-vestibular, disto-vestibular, mesial-lingual, disto-lingual), using a periodontal probe PCPUNC-15BR Hu-Friedy, São Paulo, Brazil): (a) marginal bleeding - the presence or not of bleeding was recorded by passing the periodontal probe alongside the margins of the soft tissue; (b) suppuration - presence or not of suppuration, spontaneous or when probing; (c) probing depth - distance in millimeters from the margin of the mucosa to the bottom of the sulcus or peri-implant pocket (de Mendonça et al., 2009).

Gingivitis was positive when there were more than $25 \%$ of the sites bleeding on probing, with no site showing loss of clinical insertion $>2 \mathrm{~mm}$ (Gomes-Filho et al., 2007). Patients with periodontitis: loss of insertion detected in one or more interproximal non-adjacent sites or loss of insertion of $3 \mathrm{~mm}$ or more in the vestibular or lingual/palatal in at least two teeth, as long as not caused by: a) traumatic gingival recession; b) dental cavity reaching the teeth cervical area; c) loss of insertion in the distal surface of a second molar and associated to the bad position or extraction of a third molar; d) endoperiodontal lesion draining through the marginal periodontium or e) vertical root fracture (Tonetti et al., 2018; Papanaou et al., 2017). Patients with mucositis were detected according with gingivitis parameters. Patient with peri-implantitis: a) signs of peri-implant inflammation, b) radiographic evidence of bone loss, and c) radiographic bone level $\geq 3 \mathrm{~mm}$ accompanied by bleeding on probing and probing depth $\geq 6 \mathrm{~mm}$ (Renvert et al., 2018).

For the collection of the peri-implant gingival fluid (PGF), the implants selected were isolated using sterile gauze and the sites of collection were softly dried using the air syringe. Four absorbent paper points number 40 were placed, isolated, in each site of collection, approximately $2 \mathrm{~mm}$ in the crevicular sulcus/pocket for 30 seconds each. Points contaminated by blood or saliva were discarded. Later, the points were placed in an Eppendorf tube with a 0.5 Phosphate-Buffered Saline (PBS) buffer solution, $\mathrm{pH} 7.2$, composed by $1.9 \mathrm{~g}$ monobasic potassium phosphate $\left(\mathrm{KH}_{2} \mathrm{PO}_{4}\right) ; 5.1 \mathrm{~g}$ sodium phosphate $\left(\mathrm{Na}_{2} \mathrm{HPO}_{4}\right)$; $42.5 \mathrm{~g}$ sodium chloride $(\mathrm{NaCl})$ and $500 \mathrm{ml}$ ultra-pure water, distilled in a Milli $\mathrm{Q}{ }^{\circledR}$ (Millipore) device and frozen at $-70^{\circ} \mathrm{C}$ (Escobar et al., 2018). They were sent to the UNIUBE biopathology lab. After laboratory procedures, the samples left were sterilized so later they could be discarded.

\section{Detection of bacteria in the samples}

The DNA from the studied species was extracted using the PowerLyzer PowerSoil DNA Isolation Kit (MO-BIO, 
Carlsbad, CA) according to the manufacturer's instructions. Samples were transferred to tube containing Bead Solution. After were vortexed for 2 minutes to ensure the release of bacteria to the suspension, which was then transferred to a Powerlyzer Glass Bead Tube (MO-BIO, Carlsbad, CA). The concentration of the purified DNA product was measured with a NanoDrop 2000 spectrophotometer (Thermo Scientific). Primers (synthesized by Invitrogen, Carlsbad, CA, USA) and probes (synthesized by Applied Biosystems, Carlsbad, CA, USA) were targeted against 16S rRNA genes for bacteria: Prevotella intermedia R: AATACCCGATGTTGTCCACA, Prevotella intermedia F: TTAGCCGGTCCTTATTCGAA, Scardovia wiggsiae F: GTGGACTTTATGAATAAGC, Scardovia wiggsiae R: CTACCGTTAAGCAGTAAG, Fusobacterium nucleatum F: ACCTAAGGGAGAAACAGAACCA, Fusobacterium nucleatum R: CCTGCCTTTAATTCATCTCCAT, Porphyromonas gingivalis F: TGCAACTTGCCTTACAGAGGG, Porphyromonas gingivalis R: ACTCGTATCGCCCGTTATTC. The StepOne $^{\text {TM }}$ Real-Time PCR System (Thermo Fisher Scientific) was used. Each reaction tube contained reaction mixture, including $6.5 \mu \mathrm{L}$ SYBR Green Master Mix (Roche, Ilhois, EUA), $1 \mu \mathrm{L}$ of each primer, $4.5 \mu \mathrm{L}$ de ultrapure water e $2 \mu \mathrm{L}$ of DNA extracted from samples. The cycling conditions were an initial amplification cycle of $95^{\circ} \mathrm{C}$ for $10 \mathrm{~min}$, followed by 40 cycles at $95^{\circ} \mathrm{C}$ for $15 \mathrm{~s}$ and $60^{\circ} \mathrm{C}$ for $1 \mathrm{~min}$.

\section{Statistical analysis}

The frequencies of samples with positive presence of bacteria were compared with each other and to the data obtained by the questionnaire using the Chi-square test or the Fisher's Exact Test. A value of $p<0.05$ was considered statistically significant. Data were analyzed using BioStat ${ }^{\circledR}$ Software.

\section{Results}

The data collected from the 44 eligible patients showed that their mean age was $53.2 \pm 11.7 ; 15$ were male and 29 females; 42 were white and 2 non-whites; and 22 patients had a history of periodontitis (PD). The intraoral exam, at first visit, showed that, among the volunteers, 12 had teeth in the site where the implant would take place, and would undergo extraction or immediate implantation; 12 had gingivitis and 9 periodontitis, in the tooth to be extracted or in other teeth. After 12 months, data from the interview was ratified, and the probing depth was evaluated. For 23 patients, the probing depth was lower than 1 $\mathrm{mm}$, which is normal, while 21 presented values higher than $2 \mathrm{~mm}$ and bleeding on probing, which characterized mucositis. From these, 14 had probing depths more than $3 \mathrm{~mm}$ and bleeding, but none of them had a diagnosis of peri-implantitis.

The exams for the detection of microbes in the PGF samples ( $\mathrm{n}=44$, Figure 1) showed that the Pg was detected in 15 samples (34\%). Other bacteria were detected in most samples, Fn and $\mathrm{Pi}$ in $81.8 \%(\mathrm{n}=36)$ and $\mathrm{Sw}$ in $75 \%(\mathrm{n}=33)$ of the volunteers. Comparing the detection of these bacteria in the patients with or without a history of periodontal disease, there were no statistically significant differences for the bacteria Fn, Pi, and Sw (Figure 2, p>0.05, q<0.61). However, the Pg was frequently detected in patients with a history of PD (Figure 2, p $<0.05$, q=8.19). From the 15 positive samples for Pg, 12 had a history of PD (80\%), while, from the 29 samples with no Pg detection, $65.6 \%$ had no history. 
Figure 1 - Relationship between the number of patients with positive and negative results for $\mathrm{Pg}, \mathrm{Fn}, \mathrm{Pi}$, and $\mathrm{SW}$, with or without history of PD.

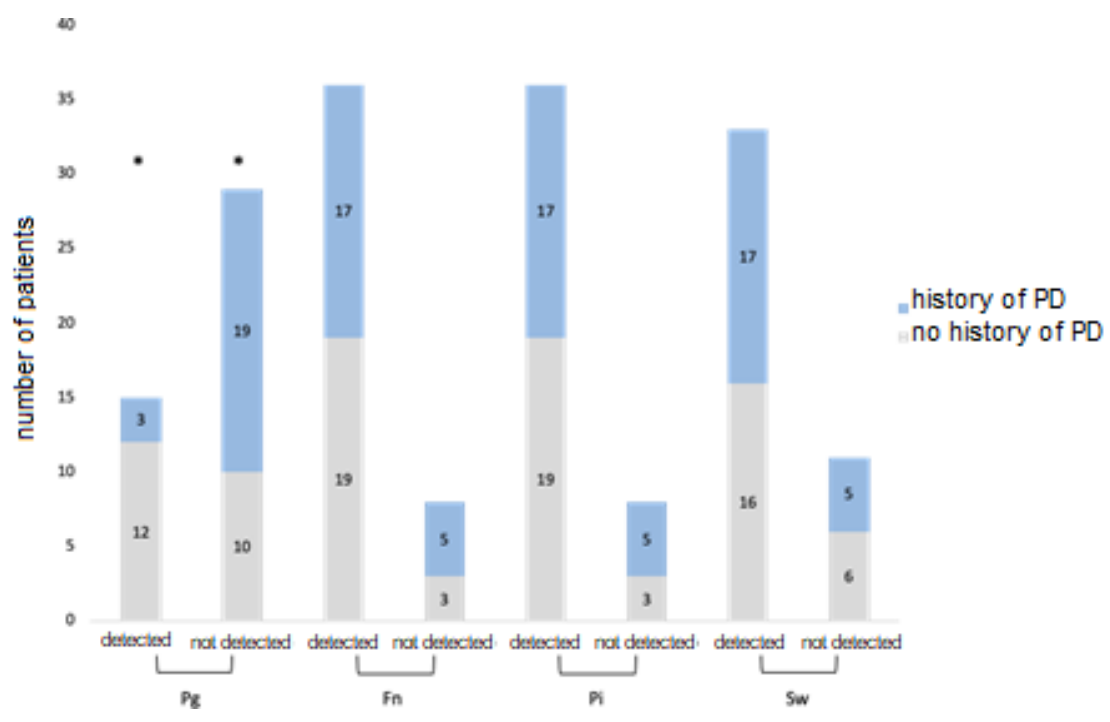

Source: Authors (2021).

The clinical data found from the patients about the presence of gingivitis and periodontitis at the time of their initial approach showed that these diseases were more frequently detected in patients with a history of PD (Table 1, $\mathrm{p}<0.05, \mathrm{q}>9.81$ ). About $83.4 \%$ and $100 \%$ of the volunteers with gingivitis and periodontitis, respectively, had a previous history of PD. There was an association between having a history of PD and having a probing depth above $2 \mathrm{~mm} 12$ months after the implant placement. From the 21 patients with this probing depth, 67\% had a history of PD (Table 1, p<0.05, q=4.46).

Table 1. List of patients with probing depth above $2 \mathrm{~mm}$ with or without a history of PD.

\begin{tabular}{cccc}
\cline { 2 - 3 } & $\begin{array}{c}\text { History of periodontal disease } \\
\text { Yes } \\
(\mathbf{n = 2 2})\end{array}$ & $\begin{array}{c}\text { No } \\
(\mathbf{n}=\mathbf{2 2})\end{array}$ & p/ $\mathbf{X}^{\mathbf{2}}$ \\
\hline $\begin{array}{c}\text { Gingivitis } \\
\text { Yes }\end{array}$ & 10 & 2 & $0.017 / 9.81$ \\
No & 12 & 2 & \\
\hline $\begin{array}{c}\text { Periodontitis } \\
\text { Yes }\end{array}$ & 9 & & $0.008 / 11.34$ \\
No & 13 & 0 & \\
\hline $\begin{array}{c}\text { Implant probing } \\
\text { depth }\end{array}$ & & 22 & \\
Normal & 8 & 15 & $0.034 / 4.46$ \\
\hline 2mm & 14 & 7 & \\
\hline
\end{tabular}

Source: Authors (2021).

The presence of teeth before the implant placement presented a positive association with the presence of $\mathrm{Pg}$. While $58.3 \%(n=7 / 12)$ of the volunteers who had teeth before showed Pg, only $25 \%$ of those who did not have teeth in the site of the implant had the bacteria in detectable levels (Figure 3, p<0.05, q=4.31). Most patients with no gingival disease or periodontitis did not have Pg in their peri-implant fluid, while the presence of Pg was associated with the presence of 
periodontitis (Figure $2 \mathrm{p}<0.05, \mathrm{q}=5.31$ ) and gingivitis (Figure 2, p<0.05, q=4.31), with 58.2\% and 66.7\% of patients with positive Pg having gingivitis and periodontitis, respectively. On the other hand, there were no statistically significant differences between the previous presence of teeth, periodontitis and/or gingivitis, and the detection of the other bacteria analyzed (Figures 3, 4 and 5, p>0.05).

Figure 2 - Relation between the presence of teeth, gingivitis and periodontitis before the implants and the detection of Pg in the crevicular fluid

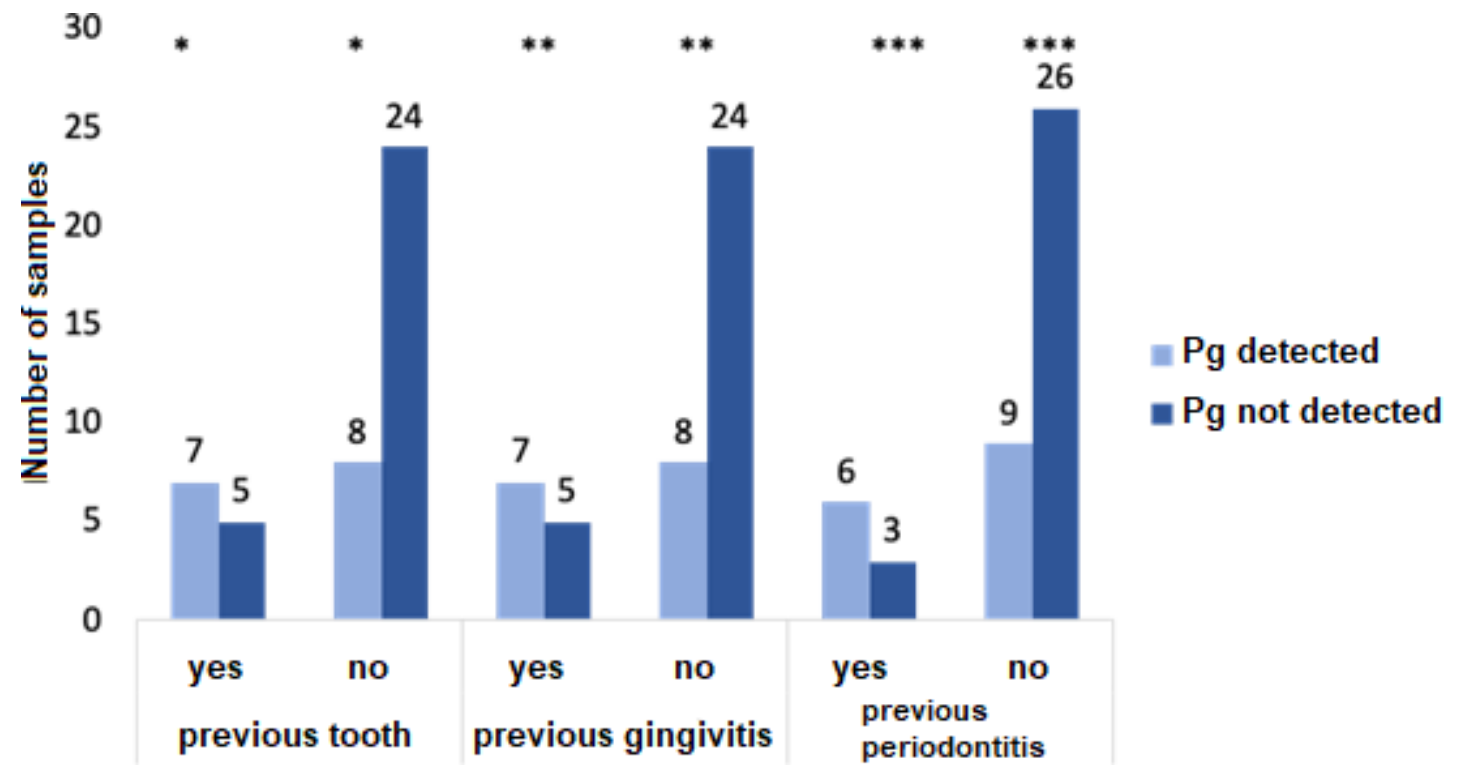

Source: Authors (2021).

Figure 3 - Relation between the presence of teeth, gingivitis and periodontitis before the implants and the detection of Fn in the crevicular fluid.

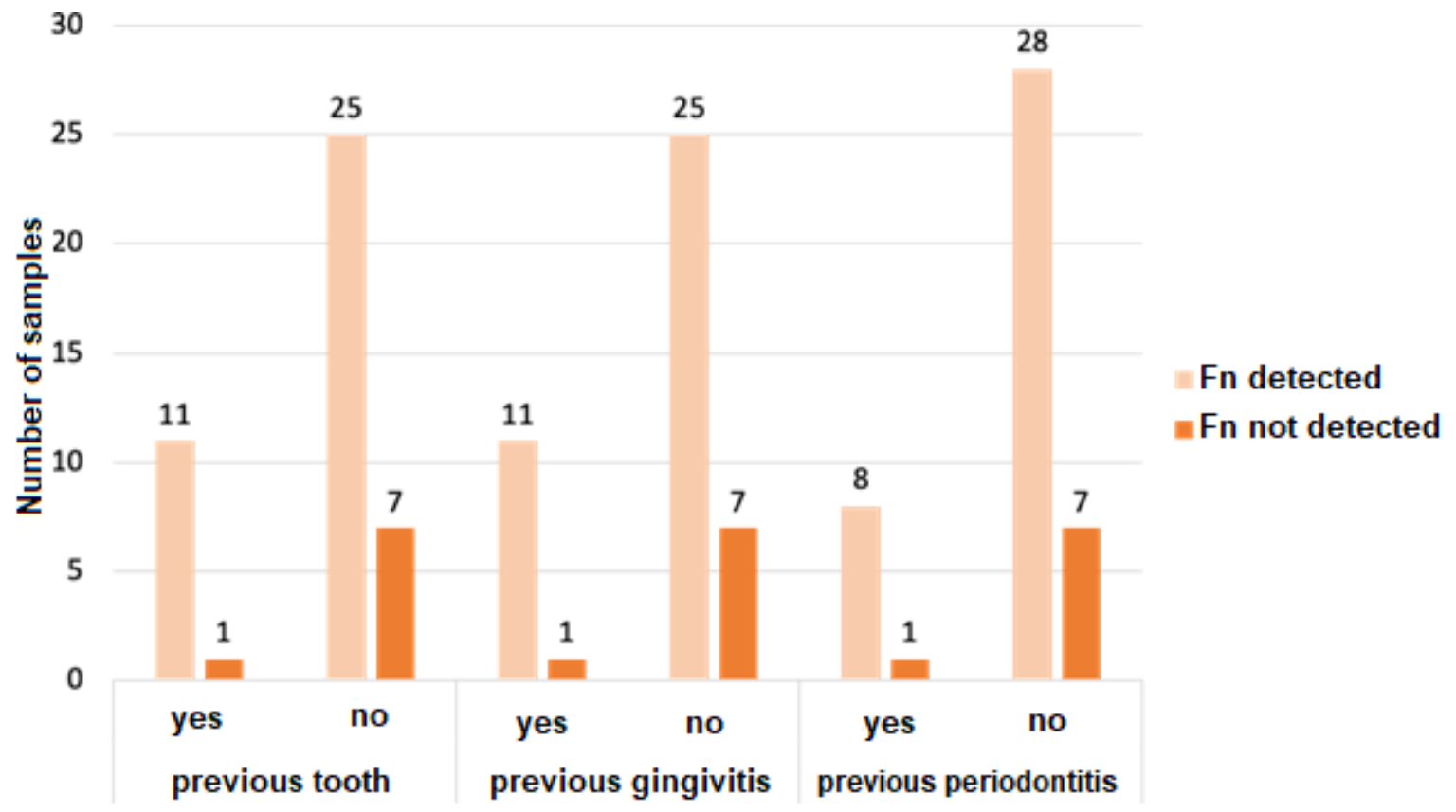

Source: Authors (2021). 
Figure 4 - Relation between the presence of teeth, gingivitis and periodontitis before the implants and the detection of Pi in the crevicular fluid.

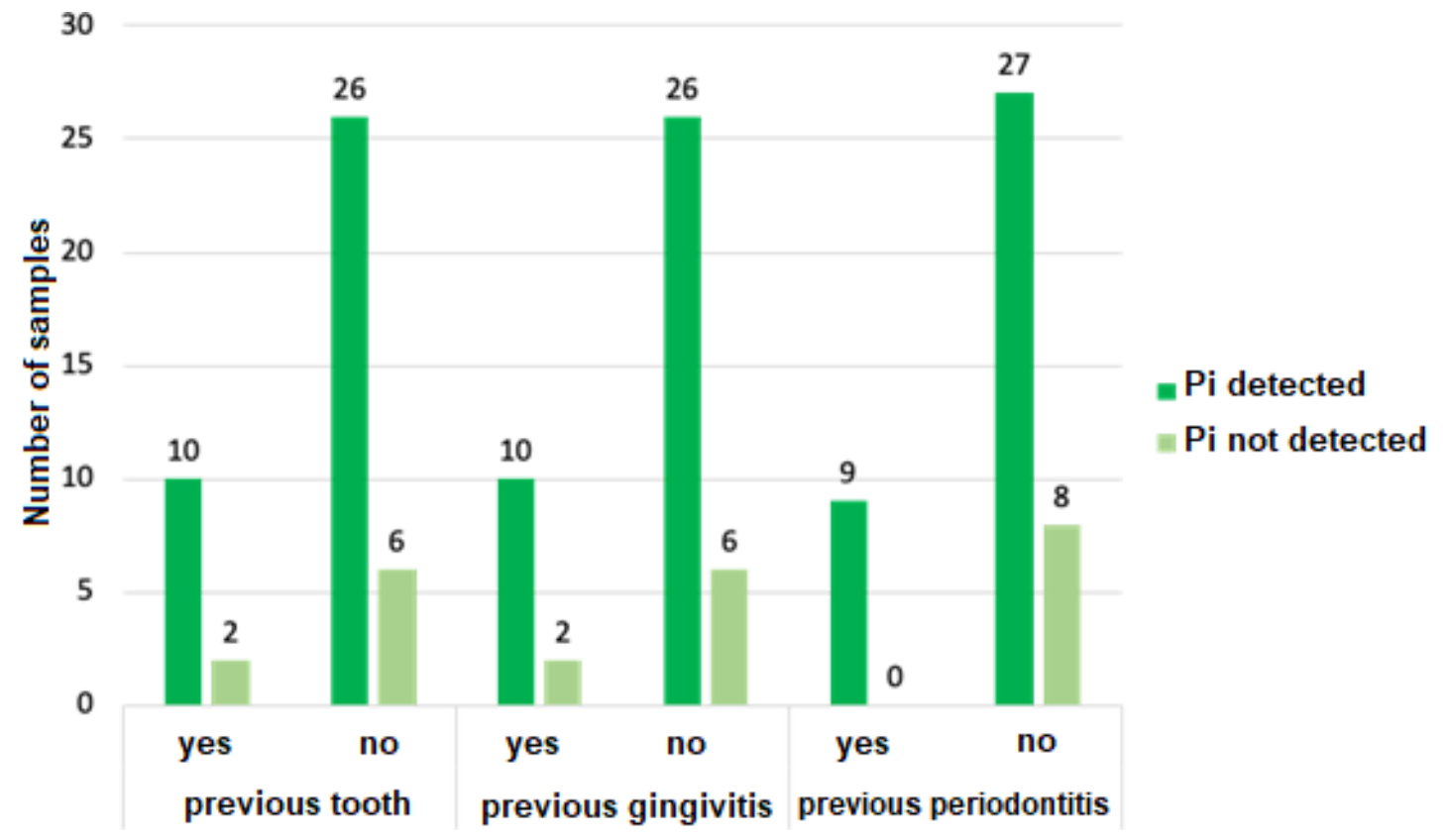

Source: Authors (2021).

Figure 5 - Relation between the presence of teeth, gingivitis and periodontitis before the implants and the detection of SW in the crevicular fluid

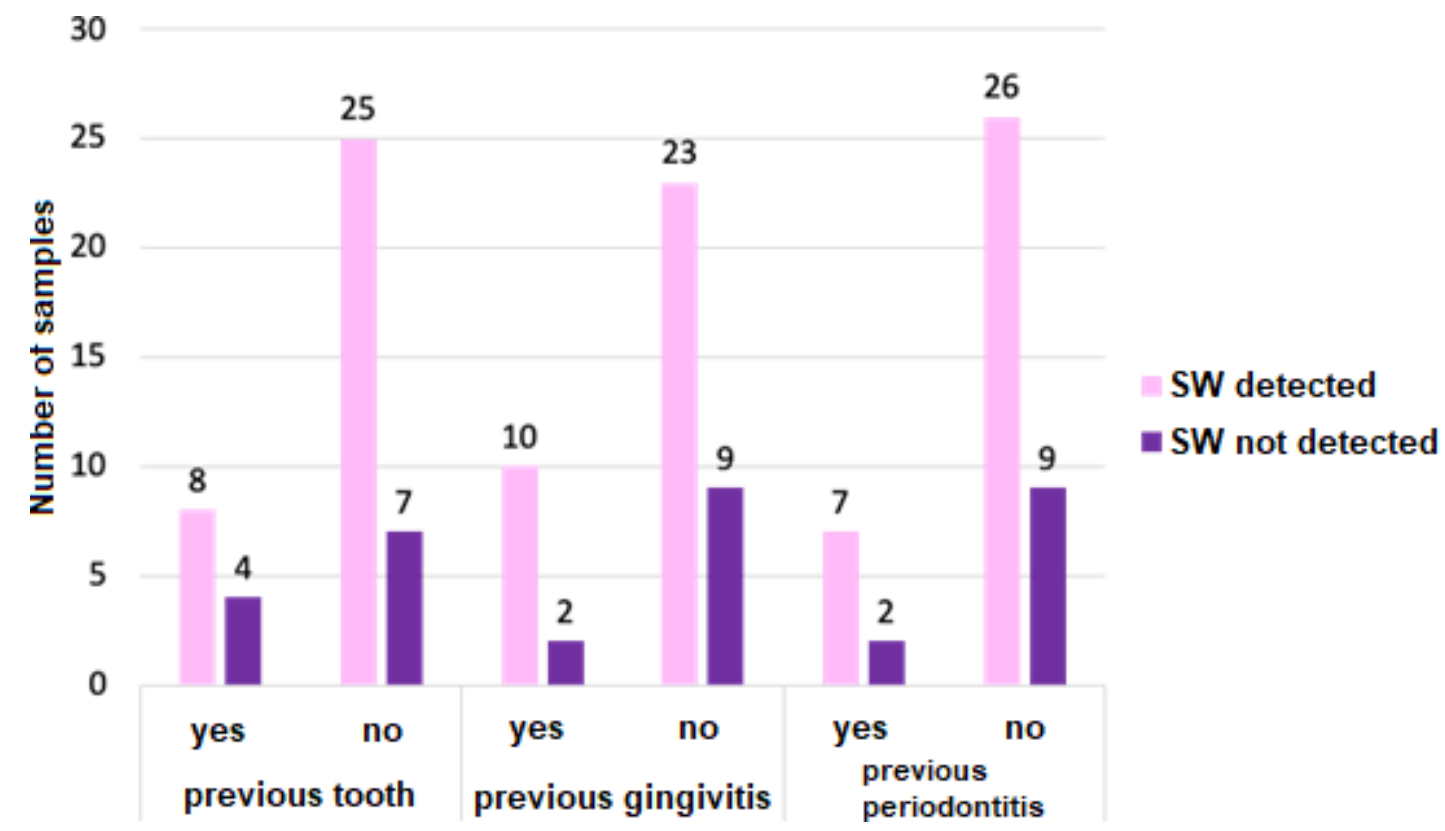

Source: Authors (2021).

The comparative analysis of the frequency of bacterial detection and the measurement of the probing depth (Table 2) showed that there is no difference between the volunteers for $\mathrm{Pg}, \mathrm{Pi}$, and $\mathrm{Sw}$ (Table 2, p<0.05). On the other hand, all patients with probing depth above $3 \mathrm{~mm}$ had detectable levels of $\mathrm{Fn}(\mathrm{p}<0.05, \mathrm{q}=4.56)$. 
Table 2 - Comparative analysis of the frequency of bacterial detection and the measurement of the probing depth.

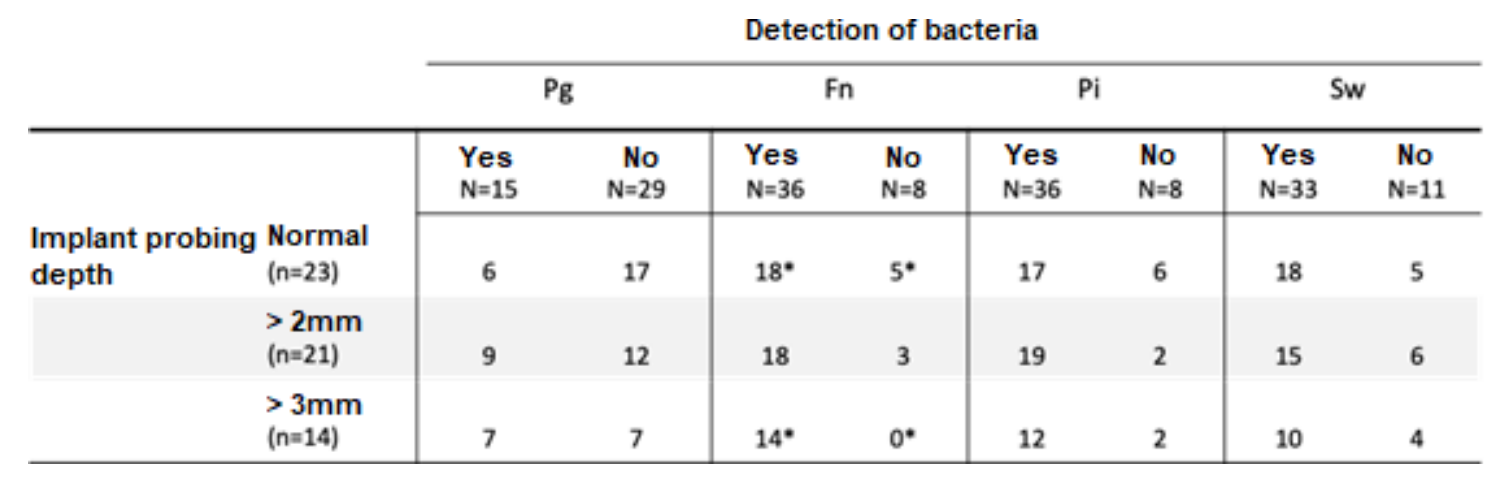

Source: Authors (2021).

\section{Discussion}

This study sought evidence about the presence of bacteria $(\mathrm{Pg}, \mathrm{Pi}, \mathrm{Fn}$, and $\mathrm{Sw}$ ) in the tooth-implant interface, in the PGF, with data about periodontal diseases (gingivitis and periodontitis) and about teeth in the location of the implant, as well as about the history of PD. The great difficulty of the study was to have patients who return after 12 months for follow-up. The results showed that Fn and Pi were frequently detected in the samples, which corroborates with a study in which these bacteria were frequently detected in PGF and involved in PD (Canullo et al., 2015). Sw was also detected in most peri-implant samples (71.7\%), which corroborates with the understanding of oral micro-environments, in addition to its involvement in the etiology of the disease (Tanner et al., 2018). The Pg was also detected in approximately 50\% of the samples, and it was the main bacteria that allowed us to observe some differences in the clinical data analyzed.

Several investigations determine some risk factors, such as a previous history of periodontitis (Heitz-Mayfield, 2008; Heitz \& Mayfield, 2009; Renvert \& Pearson, 2009), and have been investigating the issue in depth to understand and avoid the development of peri-implantitis and the consequent implant loss. Although some studies show that patients with a history of periodontitis may have healthy peri-implant tissues (Baelum e Ellegard, 2004, Karoussis et al., 2003), others have shown that patients with a history of periodontitis showed a higher risk for peri-implantitis (Quirynen et al., 2007; Heitz-Mayfield, 2008; Renvert \& Persson, 2009; Schwarz et al., 2018; Klinge et al., 2005, Ferreira et al., 2006; Cho-Yan Lee et al., 2012; Costa et al., 2012), a risk that is five times greater in patients with a history of chronic periodontitis (Karoussis et al., 2003). A systematic review and meta-analysis showed that both active periodontitis (Kabir et al., 2021) and a history of periodontitis were risk factors for peri-implantitis (Ferreira et al., 2018). The results showed that only the Pg was detected more often in patients with a history of PD.

The data analyzed did not allow us to observe a correlation between the clinical parameters and the presence of Fn, Pi, and Sw. Several studies showed that the composition of the microbiota established after the placement of the implant may remain relatively unchanged in the absence of periodontal or peri-implant pathologies, and the peri-implant sites in which PD pathogens will not necessarily develop peri-implantitis (Van Winkelhoff et al, 2000; Heydenrijk et al., 2002). Other studies showed that periodontal pathogens may be found in teeth that are in the sites of both diseased and healthy implants in the same individuals (Leonhardth et al., 1993; Mombelli et al., 1995; Rutar et al., 2001; Takanashi et al., 2002; Tabanella et al., 2009; Dabdoub et al., 2013). The same was shown in a study demonstrating that the number of Pi positive implants had similar levels to those of natural teeth 6 months after the implants placement and remained stable throughout a one-year follow-up (Leonhardt et al., 1993). On the other hand, the Pi was found more often in peri-implantitis biofilm when compared to the samples from healthy implants (Sahrmann et al., 2020). A higher prevalence of Pi in disease peri-implant sites compared with 
healthy peri-implant regions, was confirmed by a case control study (De waal et al., 2017). Furthermore, there are previous studies in which individuals with gingivitis and periodontitis were separated in two equal groups of patients. As a result, the presence of inflammation around the implant and the teeth, coupled with a history of periodontal disease were associated to an increased risk for peri-implantitis (Ferrreira et al., 2006; Cho-Yan Lee et al., 2012; Costa et al., 2012).

The frequency of $\mathrm{Pg}$ was not different than that of patients whose probing depth was above $2 \mathrm{~mm}$ and showed bleeding on probing, as shown by Ata-Ali et al. (2013). Nonetheless, according with Hayek et al. (2005), the Pg was frequently found in sites with peri-implantitis (Hayek et al., 2005, Lafaurie et al., 2017; Tzach-Nnhman et al., 2017; Zhu et al., 2019). The Pg was more frequently found in patients with a history of PD, gingivitis, periodontitis, and in the presence of the previous teeth, suggesting that its detection in the peri-implant region may be related to its transference to sites in the oral environment itself, as shown by other authors (Valente \& Adreana, 2016; Yan et al., 2020). The presence of residual periodontal pockets may cause niches for adjacent infection on implants (Mombelli et al., 1995; Karoussis et al., 2003).

An increased probing depth through time is associated with the loss of bone support (Algrafee et al., 2012). Biological complications around the implants, such as peri-implant mucositis and peri-implantitis are commonly observed a few years after the implants placement (Mombelli et al., 2012). The comparative analysis of the frequency of bacterial detection and the measurement of the probing depth showed that there is no difference between the volunteers for $\mathrm{Pg}, \mathrm{Pi}$, and $\mathrm{Sw}$. On the other hand, all patients with probing depth above $3 \mathrm{~mm}$ had detectable levels of Fn, and most of them also presented the other bacteria analyzed. Since some bacteria associated with periodontitis are commonly found in peri-implantitis, including Bacteroides, Campylobacter, Eubacterium, Fusobacterium and those from the Treponema species (Shibli et al., 2008), we can suggest that these patients, with high levels of $\mathrm{Fn}$ and of probing depths are evolving into a peri-implantitis.

Considering the above, mucositis is an inflammation process that can be detected in patients after the 12th month after the implant placement, since 21 patients (45.6\%) presented probing depth higher than $2 \mathrm{~mm}$ and bleeding on probing during the clinical examination, signs of the beginning of an inflammation. Its etiology is varied since many bacterial species may be associated with the infection process. The presence of bacteria normally found in the oral cavity can be a source of infections and lead to the accumulation of biofilm. Therefore, future studies that follow the patient for a longer period of time, continuous guidance on good oral hygiene habits and the reduction of local and systemic risk factors can better elucidate the loss or maintenance of the implant.

\section{Conclusion}

This study allowed us to conclude that:

-Sw may be present in the tooth/implant interface, and its involvement in the beginning of the peri-implant inflammatory process is not evident in our findings, since there were no statistically significant differences between clinical parameters and a history of PD.

-Among the periodontal pathogens analyzed (Pi, Pg, and Fn), the presence of Pi and Fn showed no association with gingivitis, periodontitis, history of PD, or with mucositis. However, the Fn was often detected in periodontal pockets with more than $3 \mathrm{~mm}$, which suggests its involvement in the worsening of the peri-implant inflammation process.

-The Pg was the least detected bacteria (33\%), but samples that detected it belonged to patients with a history of PD, gingivitis and periodontitis, or teeth in the sites of the implant.

-In summary, local factors, functional implants, and the time since the installation of the implant must be considered for future studies, so that base cytokine levels in the peri-implant crevicular fluid can be verified. 


\section{Declaration of human rights}

All procedures carried out in studies involving human beings were in accordance with the ethical standards of the institutional and/or national research committees and with the 1964 Declaration of Helsinki and with its later amendments or with comparable ethical standards.

\section{Acknowledgments}

This study was supported by Coordenação de Aperfeiçoamento de Pessoal de Nível Superior (CAPES).

\section{Conflict of interest}

No potential conflict of interest relevant to this article was reported.

\section{References}

Albrektsson, T \& Isidor, F. (1994) Consensus report of session IV. In: Lang N. P., Karring, T., eds. 1st Proceeding of the European Workshop on Periodontology. Quintessence Publishing, .365-369.

Algrafee, H., Borumandi, F., \& Cascarinii, L. (2012). Peri-implantitis. British Journal of Oral and Maxillofacial Surgery, 50(8), 689-694.

Altay, M. A, Tozoglu, S., Yıldırımyan, N. \& Özarslanet, M. M. (2018). Is History of Periodontitis a Risk Factor for Peri-implant Disease? A Pilot Study, Int Journal Oral Maxillofac Implants, 33 (1), 152-160.

Ata-Ali J., Fernández A. F., Ata- Ali F. \& Diago M. P. (2013). Clinical, Microbiologic, and Host Response Characteristics in Patients with Peri-implant Mucositis. International Journal of Oral \& Maxillofacial Implants, 28(3), 883-890.

Baelum, V. \& Ellegard, B. (2004).Implant survival in periodontally compromised patients. Journal Periodontol, 75(10), 1404-1412.

Belibasakis, G. N. (2014). Microbiological and mmune-pathological aspects of peri-implant diseases. Arch Oral Biol. Zurich, 59(1), 66-72.

Belibasakis, G. N., \& Manoil, D. (2021). Microbial Community-Driven Etiopathogenesis of Peri- Implantitis. Journal Of Dental Research, 100(1), 21-28. http://dx.doi.org/10.1177/0022034520949851.

Canullo, L., Oitra, D. P., Covani, U. \& Rosseti, P. H. O. (2015). Microbiologic and Clinical Findings of Implants in Healthy Condition and With Periimplantitis. Quintessence Publishing, 30(4), 834-842.

Casado, P. L; Guerra, R. R., Fonseca, M. A., Costa, L. C., granjeiro, j. M. \& Barboza, E. P. (2011). Tratamento das doenças peri-implantares : experiências passadas e perspectivas futuras- uma revisão de literatura. Revista Periodontia, 21(2), 25-35.

Cerbasi, K. P. (2010). Etiologia bacteriana e tratamento da peri-implantite; Innov Implant Journal, Biomater Esthet, São Paulo, 5(1), 50-55.

Chakrapani, A. R., Ajjappa, B. G., Prakash, S. \& Bhat, K. (2019). Scardovia wiggsiae: Role in periodontal Health and Disease - a Pilot Study. Indian J Dental $A d v, 11(4), 119-124$.

Cho-Yan Lee, J Mattheos, N., Nixon, K. C. \& Ivanovski, S. (2012). Residual periodontal pockets are a risk indicator for peri-implantitis in patients treated for periodontitis. Clinical Oral Implants Research, 23, 325-333.

Costa, F. O. (2012). Peri-implant disease in subjects with and without preventive maintenance: a 5- year follow-up. Journal of Clinical Periodontology, 39(2), $173-181$.

Daddoub, S. M; Tsigarida, A. A \& Kumar, P. S. (2013). Patient-specific analysis of periodontal and peri-implant microbiomes. Journal Dent Res, 92(12), 168175 .

De Oliveira, D. P., Ottria, L., Gargari, M. \& Candotto, V. (2017). Surface modification of titanium alloys for biomedical application: From macro to nano scale. Journal Biol. Regul. Homeost. Agents, 31(1), 221-232.

De Oliveira, M. C et al. (2015). Peri-implantite: etiologia e tratamento. Revista Brasileira de Odontologia, 72(1), 96-99.

De Waal, Y. C. M., Eijsbouts, H. V. L. C., Winkel, E. G., \& van Winkelhoff, A. J. (2017). Microbial Characteristics of Peri-Implantitis: A Case-Control Study. Journal of Periodontology, 88(2), 209-217.

Derks, J., \& Tomasi, C. (2015). Peri-implant health and disease. A systematic review of current epidemiology. Journal Clin Periodontol, 42(16), 158-171.

Diógenes, M. A et al. (2018). Mucosite periimplantar e periimplantite: Etiologia, fatores de risco e tratamento. Anais da Jornada Odontológica dos Acadêmicos da Católica, 4(1), 1-5.

Esposito, M., Grusovin, M. G., Kakisis, I., Coulthard, P. \& Worthington H. V. (2008). Interventions for replacing missing teeth: Treatment of perimplantitis. Cochrane Database of Systematic Reviews, 4, 1-13. 
Feres, M., Shibli, J. A. \& Duarte, P. M. (2008). Tratamento das doenças periimplantares; mucosite e peri-implantite - parte 1. R. Periodontia, 18(4), 1-8.

Ferreira, S. D., Silva, G. L. M., Cortelli, J. R., Costa, J. E. \& Costa, F. O. (2006). Prevalence and risk variables for peri-implant disease in Brazilian subjects. Journal of Clinical Periodontology, 33(12), 929-935.

Ferreira, S. D., Amaral, S. A., Vieira, T R ., Albuquerque B. N., Cota, L. O. M. et al. (2018). Periodontitis as a risk factor for peri-implantitis: systematic review and meta- analysis of observational studies. Journal Dent, 79, 1-10.

Francio, L., Sousa, A. M. de, Storrer, C. L. M., Deliberador, T. M., Pizzato, E. \& Lopes, T. R. (2008). Tratamento da periimplantite: revisão da literatura. Revista Sul Brasileira de Odontologia, 5(2), 75-8.

Furst, M. M., Salvi G. E., Lang, N. P. \& Persson G. R. (2007). Bacterial colonization immediately after installation on oral titanium implants. Clin Oral Implants Res, 18(4), 501-508.

Hayek, R. R. A et al. (2005). Estudo comparativo entre os efeitos da terapia fotodinâmica e da terapia convencional na redução microbiana na peri-implantite induzida por ligadura em cães. Journal Periodontol, 76(8), 1275-1281.

Heitz-Mayfield, L. J. A. (2008). Peri-implant diseases: diagnosis and risk indicators. Journal Clin Periodontol, 35(8), 292-304.

Heitz-Mayfield L. J. A. \& Huynh-Ba, G. (2009). História de periodontite tratada e tabagismo como riscos para a terapia com implantes. Implantes Maxilofac Orais Int J. 24, 39-68.

Heitz-Mayfield, L. J. A. \& Salvi G. E. (2018). Journal Clin Periodontol, 45 (20), 237-245

Heydenrijk , K., Meijer H. J .A. , Reijden, W. A. V., Raghoebar, G. M. , Vissink, A. \& Stegenga B. (2002). Microbiota around root-form endosseous implants: a review of the literature. Int J Oral Maxillofac Implants, 17(6), 829-838.

Kabir L, Stiech M \& Grischke J. (2021). The efect of keratinized mucosa on the severity of peri- implant mucositis difers between periodontally healthy subjects and the general population: a cross-sectional study. Clin Oral Invest, 25(3), 1183-1193.

Karoussis I. K., Salvi, G. E., Heitz-Mayfield L. J. A., Brägger, U., Hämmerle, C. H. F. \& Lang, N. P. (2003). Long-term implant prognosis in patients with and without a history of chronic periodontitis: a 10 year prospective cohort study of the ITI Dental Implant System. Clin Oral Implants Res, 14(3), 329-339.

Klinge, B; Hultin M. \& Berglundh, T. (2005). Peri-implantitis. Dent Clin North Am, 49(3), 661-676.

Kocar, M.; Seme K., \& Hren N. I. (2010). Characterization of the normal bacterial flora in peri- implant sulci of partially and completely edentulous patients. Int J Oral Maxillofac Implants, 25(4), 690-698.

Kroger, A. et al. (2018). The severity of human peri-implantitis lesions correlates with the level of submucosal microbial dysbiosis. Journal of Clinical Periodontology, 45, 1498-1509.

Kumar P. S. (2019). Fatores de risco sistêmico para o desenvolvimento de doenças peri- implantes. Implant Dent, 2, 115-119.

Lafaurie G. I., Sabogal, M. A. Castillo, D. M., Rincón M. V., Gómez L. A., Lesmes, Y. A., et al. (2017). Microbiome and microbial biofilm profiles of PeriImplantitis: a systematic review. Journal Periodontol, 88(10), 1066-1089.

Leonhardth, A., Adolfsson, B., Lekholm U., Wikström, M. \& Dahlén, G . (1993). A longitudinal microbiological study on osseointegrated titanium implants in partially edentulous patients. Clinical Oral Implants Research, 4(3), 113-120.

Lindhe J.L. N \& Karring, T. (2010). Tratado de Periodontia Clínica e Implantologia Oral. 5th ed. Rio de janeiro: Guanabara Koogan..

Lindhe, J L. N \& Meyle, J. (2008). Group D of European Workshop on Periodontology Periimplant diseases: consensus report of the sixth European Workshop on Periodontology. Journal Clin Periodontol, 35(8), 282-285.

Louropoulou, A. et al. (2012). Titanium surface alterations following the use of diferente mechanical instruments: A systematic review. Clin Oral Implants Res, 23(6), 643-658.

Martins, E. O. B., Martins F., Anjos, E. D. \& Marques, D. D. M. (2019) Doenças periimplantares, etiologia, diagnóstico e classificação: revisão de literatura. Brazilian Journal of Periodontology, 29(1), 53-64.

Mavrogenis, A. F., Dimitriou, R., Parvizi, J. \& Babis G.C. (2009). Biology of implant osseointegration. Journal Musculoskelet Neuronal Interact, 9(2), 61-71.

Mendes, V.C \& Davies J.E. (2016). Uma nova perspectiva sobre a biologia da osseointegração. Revista da Associação Paulista de Cirurgiões Dentista, 70(2), 166- 71 .

Mombelli, A, Marxer, M., Gaberthüel, T., Grunder, U. \& Lang, N. P. (1995). The microbiota of osseointegrated implants in patients with a history of periodontal disease. Journal Clin Periodontol, 22(2), 124-130.

Mombelli, A., Muller, N \& Cionca, N. (2012). The epidemiology of peri-implantitis. Clinical Oral Implants Research, 23(6), 67-76.

Mombelli, A., Nyman, S., Brägger, U. , Wennström, J. \& Lang, N. P. (1995). Clinical and microbiological changes associated with an altered subgingival environment induced by periodontal pocket reduction. J Clin Periodontol, 22(10), 780-787.

Ogle, O. E. (2015). Implant surface material, design, and osseointegration. Dent. Clin. N. Am, 59(2), 505-520.

Oliveira-Neto, O. B., Lemos C. A. A., Barbosa, F. T., de Sousa-Rodrigues C. F. \& Camello de Lima, F. J. (2019). Immediate dental implants placed into 
infected sites present a higher risk of failure than immediate dental implants placed into non-infected sites: systematic review and meta-analysis. Med Oral Patol Oral Cir Bucal, 24(4), 518-528.

Ottria, L., Lauritano, D., Bassi, M. A., Palmieri, A , Candotto, V, Tagliabue, A. et al. (2018). Mechanical, chemical and biological aspects of titanium and titanium alloys in implant dentistry. Journal Biol. Regul. Homeost. Agents. 32 (1), 81-90.

Petkovic-Curcin, Matić A. S., Danilo V., Stamatović, N. \& Todorović, T. (2011). Cytokines in pathogenesis of peri-implatitis.mVojnosanitetski pregled, 68(5), 435-440.

Petrasunas, K. (2010). Etiologia bacteriana e tratamento da peri-implantite. Innov. Implant. Journal Biomater Esthet, 5(1), 50-55.

Pita, P. P. C. (2015). Adesão de estreptococos orais em diversas superfícies de implantes. 33f. Dissertação (Mestrado)-curso de Odontologia, Implantodontia, Universidade de Guarulhos, Guarulhos, Brasil.

Quirynen, M., Abarca, M., Assche, N. V., Nevins, M. \& Steenberghe, D. V. (2007). Impact of supportive periodontal therapy and implant surface roughness on implant outcome in patients with a history of periodontitis. Journal of Clinical Periodontology, 34(9), 805-815.

Renvert, S. \& Persson, G. R. (2009). Periodontitis as a potential risk factor for peri-implantitis. Journal of Clinical Periodontology, 36 (1), 9-14.

Renvert, S., Persson G. R. Pirih, F. Q. \& Camargo, P. M (2018). Peri-implant health, peri-implant mucositis and peri-implantitis: case definitions and diagnostic considerations. Journal Clin Periodontol, 45(20), 278-285.

Romeiro, R. L., Rocha R. F. \& Antonio O. C. J. (2010). Etiologia e tratamento das doenças periimplantares. Revista Metodista, 18(36), 59-66.

Rutar, A., Lang, N., Buser, D., Bürgin, W. \& Mombelli, A. (2001). Restrospective assessment of clinical and microbiological factors affecting periimplant tissue conditions. Clin Oral Impl Res. 12, 189-195.

Sahrmann, P., Gilli F., Wiedemeier, D. B , Attin T., Schmidlin, P. R \& Lamprini K. (2020). The Microbiome of Peri-Implantitis: A Systematic Review and Meta- Analysis. Microorganisms, 8(5), 661.

Salvi G. E., Fürst, M. M., Lang, N. P. \& Persson, G. R. (2008). One-year bacterial colonization patterns of Staphylococcus aureus and other bacteria at implants and adjacent teeth. Clin Oral Implants Res, 19(3), 242-248.

Sanz, M. \& Chaple, I. L. (2012). Clinical research on peri-implant diseases: consensus report of Working Group 4. Journal Clin Periodontol. 39 (12), 202-206. Schwarz, F., Derks, J., \& Monje, A. W. H. (2018). Peri-implantitis. Journal of Periodontology, 89(1), 267-290. doi:10.1002/jper.16-0350

Shibli, J.A. \& D'avila, S. (2006). Restoration of the soft-tissue margin in single-tooth implant in the anterior maxilla. Journal of Oral Implantology, 32(6), 286-290.

Shibli, J.A., Melo, L., Ferrari, D. S., Figueiredo, L. C., Faveri , M. \& Feres, M. (2008).Composition of supra- and subgingival biofilm of subjects with healthy and diseased implants. Clin Oral Implants Res. 19(10), 975-982.

Sobreira, F. M., Junior, G. R de S., Lopes, N. M. A \& Cimões A. V. R., (2011). Peri-implantite: Bases científicas para diagnóstico e tratamento. Inter Journal of Dentistry, 10(3), 180-185.

Tabanella, M. S. G., Nowzari H. \& Slots J. (2009). Clinical and Microbiological Determinants of Ailing Dental Implants, Clinical Implant Dentistry and Related Research, 11(1), $24-36$.

Tallarico M., Canullo, L., Caneva, M. \& Özcan, M. (2017). Colonização microbiana na interface implante-pilar e sua possível influência na periimplantite: uma revisão sistemática e metanálise. J Prótese Res, 61(3), 233-241.

Takanashi, Y., Penrod, J. R., Chehade, A., Klemetti, E., Savard, A., Lund, J. P. \& Feine, J. S. (2002). Does a Prosthodontist Spend More Time Providing Mandibular Two-Implant Overdentures than Conventional Dentures? Int J Prosthodont, 15(3), 397-403.

Tanner, A. C. R., Kressirer, C. A., Rothmiller, S., Johansson, I. \& Chalmers, N. I (2018). The Caries Microbiome: Implications for Reversing Dysbiosis ReviewAdv Dent Res, 29(1), 78-85.

Tanner, A. C. R., Sonis, A., Holgerson, P. L., Starr, J. R., Nunez, Y., Kressirer, C. A., Paster, B. J., \& Johansson, I. et al. (2012). White-spot lesions and gingivitis microbiotas in orthodontic patients. J Dent Res, 91(9), 853-858.

Tzach-Nahmanr, R, Mizraji, G., Shapira, L., Nussbaum, G. \& Wilensky, A. s. (2017). Oral infection with Porphyromonas gingivalis induces peri- implantitis in a murine model: evaluation of bone loss and the local inflammatory response. Journal Clin Periodontol, 44(7), 739-48.

Valente, N.A \& Adreana, S. (2016). Peri-implant disease: what we know and what we need to know. Journal Periodontal Implant Sci. New York, 46(3) 136151.

Van- Winkelhoff A. J., Goené R. J., Benschop, C. \& Folmer, T. (2000). Early colonization of dental implants by putative periodontal pathogens in partially edentulous patients. Clinical Oral Implants Research, 11(6), 511- 520.

Wang, W., Lagoudis, M., Yeh, C. \& Paranhos, K. S. (2017). Management of peri-implantitis a contemporary synopsis. Singapore Dent. Journal, $38,8-16$.

Yan, X., Lu, H., Zhang, L. , Zhu, B., Piao, M., Huang, B., Zhang, H. \& Meng, H. (2020). A three-year study on periodontal microorganisms of short lockingtaper implants and adjacent teeth in patients with history of periodontitis. Journal of Dentistry, 95, 1-8.

Zitzmman, N. U., Scharer, P. \& Marinello, C P. (2001). Long-term results of implants treated with guided bone regeneration: A 5-year prospective study. The International Journal of Oral\& Maxillofacial Implants, 16(3), 355-366.

Zhu, B., Meng, H., Huang, B., Chen, Z. \& Lu, R. (2019). Detection of T-forsythia and other important bacteria in crestal and subcrestal implants with ligatureinduced peri-implant infection in dogs. Journal Periodontol, 90(3), 306-13. 